joined the Indian Civil Service in 1887. Throughout his service he had taken much interest in the people of the Bombay Presidency, especially in their customs and traditions, and in anthropological matters generally. The knowledge thus acquired was embodied in two standard works, Tribes and Castes of Bombay and The Folklore of Bombay. Retiring in 1920 as Commissioner of Customs, Salt, and Excise, Bombay, Enthoven settled in England, and served most usefully for many years on the Council of the Society.

P. R. CADELL.

\title{
Sir Charles G. H. Fawcett
}

Sir Charles Gordon Hill Fawcett died in March, 1952, in his eighty-third year. Born in 1869 he was educated at Harrow and Pembroke College, Cambridge, and entered the Indian Civil Service in 1890 , being posted to Bombay, where he served for many years, becoming a Judge of the High Court. He had shown his interest in the early years of the British connection with India by contributions to the Journal of the Bombay Branch of the Royal Asiatic Society and, after his retirement, he combined this interest with his judicial knowledge in the production of his book The First Century of British Justice in India. He also edited the first volumes of the new series of English Factories in India, and for the Hakluyt Society the Travels of Abbé Carré, which were translated by his wife from the original French manuscript. He also edited Sir Evan Cotton's unfinished East Indiamen, an account of the East India Company's maritime service. All his work was marked by extreme care and accuracy.

\section{P. R. CADELL.}

\section{Ernest Herbert Cooper Walsh}

Ernest Herbert Cooper Walsh, C.S.I., whose death has occurred at the age of 87, was from 1907 a member of this Society. In India he was (1901-1919) a member of the Asiatic Society of Bengal ; in the Bihar and Orissa Research Society he served as Vice-President (1917-18), President (1919), and Secretary for Archæology and Numismatics, and on retirement was elected an Honorary Member. After returning to England (1920) he was Lecturer in Tibetan at the London School of Oriental Studies (1920) and Lecturer in Bengali 
in the University of Oxford (1920-21). His contributions to Oriental Studies appeared mostly in the publications of the three Societies; but two, namely " $A$ Vocabulary of the Tromowa dialect of Tibetan spoken in the Chumbi Valley (1905), and Examples of Tibetan Letters (1913) were issued by the Bengal Secretariat.

Walsh's interest in Tibet, which may have begun when he was (1901) Deputy Commissioner at Darjeeling, must have been stimulated by participation in the Younghusband mission to Lhasa (1903-4), which as late as 1938 he recalled in a note on the topography of the city and by publishing his own photograph of the famous Buddha statue in the Jo-khan, with correction of the depreciation of the statue as a work of art. He published two short Memoirs (A.S.B., I, 13, and II, 2), on a cup-mark " inscription" in the Chumbi valley (1906) and on the "Coinage of Tibet" (1907), and, in the JRAS., 1910, the most valuable of his Tibetan studies, a detailed account of the Tibetan anatomical system, according to a diagram procured in Lhasa: with the fully acknowledged assistance of a native physician the system and many particulars were clarified. His "Examples of Tibetan Letters" includes, with transliterations and translations, plates exemplifying the many styles of script in use, some far more easily read by native postmen than by outside scholars : previously Csoma Körösi, B. H. Hodgson, and S. C. Das had provided similar convenient models. In 1915 followed (JRAS.) two notes on "Examples of Tibetan seals".

Walsh's second main subject, numismatics, is represented by his paper (JRAS. 1908) on the "Coinage of Nepal", and, far more substantially, by several elaborate articles on punch-marked coins, first inspired by a large find at Patna (JBORS., 1919), but continued even as late as 1938 (JRAS.). His interest in the Bengali language and in Orissa, where he had served as Settlement Officer long before becoming a member of the Board of Revenue for Bihar and Orissa, was manifested by serious and helpful reviews in this Journal.

Walsh was a sound, well-informed, and exact scholar, always contributing new knowledge, unegotistical, appreciative of help, and with a somewhat practical bent : these qualities give permanent value to his work.

Born in 1865 (March 7) son of the Rev. Thomas Harris Walsh, of Reddings Vicarage, Derbyshire, he was educated at Trent College and at University College, London, becoming also a member of the 
Middle Temple. In the Indian Civil Service, which he joined in 1884, he held high appointments which, being recorded in the India Office List and Who's Who and summarized in The Times obituary, may here be passed over. By his marriage (1892) to Beatrice Ivy, daughter of the Rev. H. Huntingdon, British Government Chaplain at Leghorn, he had two daughters, who survive their mother (d. 1943) and him.

F. W. Thomas.

September, 1952. 